\title{
TREATMENT OF PATIENTS WITH SCHISTOSOMIASIS MANSONI: A DOUBLE BLIND CLINICAL TRIAL COMPARING PRAZIQUANTEL WITH OXAMNIQUINE
}

\author{
Lưz Caetano da silva (1), José Murilo R. ZeITUNe (1), Lucia Maria F. ROSA-ELD (2), Dirce Mary \\ C. LIMA (1), Rita f. ANTONELll (1), Carlos H. CHRisto (1), amadeo SaEz-Aledezar (3) \\ \& Adriany de Castro CARBONX (3)
}

\section{S U M M A R Y}

A double-blind clinical trial involving 120 patients with chronic schistosomiasis was carried out to compare the tolerability and efficacy of praziquantel and oxamniquine. The patients were randomly allocated into two groups. One was treated with praziquantel, $55 \mathrm{mg} / \mathrm{kg}$ of body weight (BWT), and the other one with oxamniquine, $15 \mathrm{mg} / \mathrm{kg}$ bwt, administered in a single oral dose. The diagnosis and the parasitological follow-up was based on stool examinations by quantitative Kato-Katz method and on rectal biopsies. Side-effects - mainly dizziness, sleepness, abdominal distress, headache, nausea and diarrhea - were observed in $87 \%$ of the cases. Their incidence, intensity and duration were similar for both drugs but abdominal pain was significantly more frequent after praziquantel intake and severe dizziness was more commonly reported after oxamniquine. A significant increase of alanine-aminotransferase and $\gamma$ glutamyltransferase was found with the latter drug and of total bilirubin with the former one. A total of 48 patients treated with praziquantel and 46 with oxamniquine completed with negative findings the required three post-treatment parasitological controls - three slides of each stool sample on the first, third and sixth month. The achieved cure rates were $79.2 \%$ and $84.8 \%$, respectively, a difference without statistical significance. The non-cured cases showed a mean reduction in the number of eggs per gram of feces of $93.5 \%$ after praziquantel and of $84.1 \%$ after oxamniquine. This diference also was not significant. Five patients retreated with praziquantel were cured but only one out of three treated a second time with oxamniquine. These findings show that both drugs - despite their different chemical structures, pharmacological properties and mechanisms-of-action - induce similar sideeffects as well as a comparable therapeutical efficacy, in agreement with the results reported from analogous investigations.

KEY WORDS: Schistosomiasis mansoni - Treatment - Praziquantel - Oxamniquine

\section{N T ROD U GTION}

Chemotherapy in a single-dose schedule with potent drugs represented a breakthrought in the treatment of schistosomiasis mansoni 9. The first one was hycanthone, mainly administered

(1) Instituto de Medicina Tropical de Săo Paulo, Av. Dr. Enéas de Carvalho Aguiar 470, 05403 Sāo Paulo, Brasil.

(2) Bolsista da Fundaçăo E. J. Zerbini, Inst. Med. Tropical S. Paulo

(3) Laboratorio de Cirurgis do Aparelho Digestivo, Faculdade de Mediicna da V.S.P. 
SIIVA, L. C, da; ZEITUNE, J. M. R.; ROSA-EID, L. M. F.; LIMA, D. M. C.; ANTONELLI, R. H.; CHRISTO, C. H. SADZALQUEZAR, A. \& CARBONI, A. de C. - Treatment of patients with schistosomiasis: B double blind clinical trial comparing praziquantel with oxamniquine. Rev. Inst. Med, trop. Sāo Paulo, 28:174-180, 1986.

by intramuscular route. Unfortunately, some cases of fatal toxic hepatitis 4,6 and drug resistance 1,5 were repr)rted.

With the appearance of oxamniquine, hycanthone was rapidly withdrawn and it is no longer available in Brazil.

Over the last 10 years oxamniquine, a tetra hydroquinoline derivative, has been extensively used in our country, not only for individual treatment 28 but also as mass treatment 18 . Interesting enough this drug showed a greater efficacy against the Brazilian strain of Schistosoma mansoni than against the African strain ${ }^{18}$.

Despite its good tolerability oxamniquine may cause unwanted side-effects such as: severe dizziness, mostly in fasting conditions 28; neurological disturbances in animals 15 and in humans ${ }^{18}$ and occasionaly seizures 2,25 . Moreover, elevation of serum activity of aminotransferases a few days after treatment has been reported in some patients with schistosomiasis 28 . On the other hand, cases of resistance to oxamniquine have been published 10,16,29, and finally its efficacy in humans was recently disputed in our country ${ }^{8}$.

These findings justified further investigations with new antischistosome agents. Praziquantel, a heterocyclic pyrazino-isoquinoline compound, is a relatively new drug jointly developed by E. Merck - Darmstadt and Bayer AG - Leverkusen. It was found to be particularly active against Schistosoma mansoni, $\mathbf{S}$. haematobium and $\mathbf{S}$. japonicum, the three main species pathogenic to $\operatorname{man} 19,24,26,32$.

In order to compare the tolerability and efficacy of praziquantel and oxamniquine, this double-blind clinical trial was carried out.

\section{MATERIAL AND METHODS}

One hundred and twenty patients with chronic intestinal or hepato-intestinal forms of schistosomiasis were included in the trial.

The selection of patients was based on age (oider than 14 years), clinical form (hepaiosplenic cases were not included) and worm burden established by three pre-treatment excretal egg counts according to Kato-Katz me- thod ${ }^{17}$. Patients with associated acute and or serious diseases and those who were pregnant or who have been treated within the previous 6 months with any anti-schistosomal drug were excluded.

After parasitological diagnosis, the 120 patients were randomly allocated into two groups having an equal number of cases. One received praziquantel $55 \mathrm{mg} / \mathrm{kg}$ bwt and the other group oxamniquine $15 \mathrm{mg} / \mathrm{kg}$ bwt. Both drugs were given in a single oral dose in accordance with a double-blind technique.

Evaluation of symptoms and physical examination were performed on the same day and 24 to 48 hours after the drug administration. Report of side-effects was attained through the spontaneous information of the patients.

Blood was collected just before, 24 to 48 hours and on the 7th. day after treatment. The following tests were accomplished: alanineaminotransferase (ALT); aspartate-aminotransferase (AST); gammaglutamyl-transferase; and bilirubin.

One patient was not included in the evaluation of tolerance and toxicity as he was inadvertently treated with oxamniquine at the beginning of an assymptomatic viral hepatitis. The evolution was uneventful.

The assessment of drug efficacy was based on three slides of each stool sample obtained prior to as well as one, three and six months after tretment ${ }^{21}$. In 73 out of 77 patients with negative stool examinations up to the sixth month, 4 to 6 biopsies were taken from the valves of Houston during rectoscopy, always performed by the same investigator.

Patients with less than three negative posttreatment parasitological controls were not included in the assessment of efficacy but all cases who eliminated viable eggs in any stool examination from the first month on after treatment were considered as noncured; whenever feasible they were retreated with the same drug. The shortest period between both treatments was four months.

For the statistical analysis 14,31 of side-effects tables of contingency $2 \times 3$ were constructed, and the hypothesis of homogeneity between the two 
SILVA, L. C. da; ZEITUNE, J. M. R.; ROSA-EID, L. M. F.; IMMA, D. M. C.; ANTONEILI, R. H.; CHRISTO, C. H.; SAFA-ALQUEZAR, A. \& CARBONI, A. de C. - Treatment of patients with schistosomiasis: a double blind clinical trial comparing praziquantel with oxamniquine. Rev. Inst.. Med. trop. Säo Paulo, 28:174-180, 1986.

groups was tested by the Pearson's statistic. A "one-sample profile analysis" was utilized to evaluate the biochemical data; for comparing the therapeutical efficacy it was applied the chi-square test and the Mann-Whithney test to confront the reduction of eggs eliminated by the non-cured cases. Calculations were done by using the software Statistical Analysis System.

\section{RESULTS}

\section{Clinical and parasitological findings}

Sex, age, body-weight and egg counts from patients of the two groups were compared and no significant difference $(p>0.05)$ was found (Table I). All but three patients had more than $100 \mathrm{~S}$. mansoni eggs per gram of stools.

T A B I I I

Clinical and parasitological findings on 120 patients with chronic schistosomiasis mansoni treated with praziquantel or oxamniquine

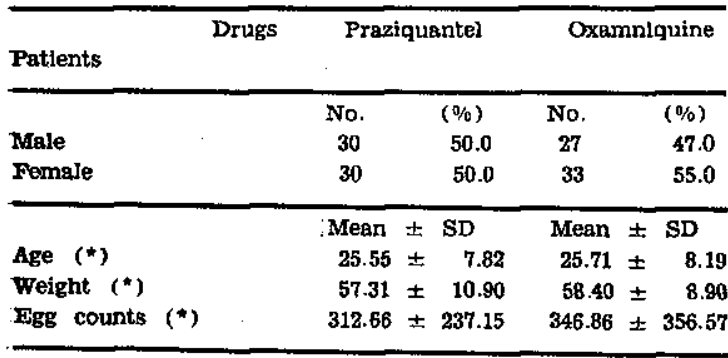

(*) $p>0.05$ (N.S.)

\section{Tolerability}

Side-effects following the administration of praziquantel or oxamniquine were observed in 53 out of 60 patients $(88.3 \%)$ and in 51 out of $59(86.4 \%)$, respectively. The main complaints were dizziness, sleepness, abdominal pain or disconfort, headache, nausea and diarrhea. (Table II). Abdominal pain was significantly more frequent $(p<0.001)$ after praziquantel intake. A severe degree of dizziness occurred in 13 out of 59 cases $(22.0 \%)$ after oxamniquine, and in 5 out of $60(8.3 \%)$ after praziquantel but this difference was not significant $(p>0.1)$. Most of the symptoms disappeared without additional medication within a few hours.

\section{Biochemical data}

T A B L I II

Occurrence of side-effects after praziquantel and oxamniquina treatmont

\begin{tabular}{|c|c|c|c|c|}
\hline $\begin{array}{l}\text { Drugs } \\
\text { Dose }\end{array}$ & $\begin{array}{c}\text { Praz } \\
55\end{array}$ & $\begin{array}{l}\text { antel } \\
\text { /kg }\end{array}$ & $\begin{array}{r}\text { Oxam } \\
15 r\end{array}$ & $\begin{array}{l}\text { uine } \\
\mathbf{k g}\end{array}$ \\
\hline Side-effects & No. & $(\%)$ & No. & $(\%)$ \\
\hline None & 7 & 11.7 & 8 & 13.6 \\
\hline Dirainess $(*)$ & 36 & 60.0 & 38 & 64.4 \\
\hline Abdominal distress $\left({ }^{* *}\right)$ & 29 & 48.3 & 10 & 26.3 \\
\hline Sleepness (*) & 21 & 35.0 & 16 & 27.1 \\
\hline Nausea (*) & 14 & 23.3 & 11 & $18 \cdot 6$ \\
\hline Headache (*) & 12 & 20.0 & 15 & 25.4 \\
\hline Diarxhea (*) & 12 & 20.0 & 4 & 6.8 \\
\hline Vomiting & 7 & 11.7 & 9 & 15.3 \\
\hline Itching & 4 & 6.7 & 2 & 3.4 \\
\hline Anorexia & 1 & 1.7 & 3 & 5.2 \\
\hline Myalgia & - & - & 3 & 5.1 \\
\hline Asthenia & 1 & 1.7 & - & - \\
\hline
\end{tabular}

Table III displays the data obtained before $T_{0}$, two days $\left(T_{2}\right)$ and 7 days $\left(T_{7}\right)$ after chemotherapy.

According to Wilks (W) and Fisher-Snedecor's (F) statistics, significant changes were observed with alanine-aminotransferase $(p<$ $0.05)$ and gammaglutamyltransferase $(p<0.01)$ after oxamniquine and with total bilirubin $(\mathrm{p}<$ 0.05 ) after praziquantel. In order to study the influence of time on these changes, the abovementioned liver function tests were further submitted to statistical analysis with the same methods. The results are shown in Table IV. A significant difference was observed between $T_{0}$ and $T_{7}$ and $T_{2}$ and $T_{7}$ for ALT and GGT after oxamniquine. For TB after praziquantel a significant difference was observed between $\mathrm{T}_{2}$ and $\mathrm{T}_{7}$.

\section{Efficacy}

The parasitological follow-up examinations were completed in 94 patients. In the praziquantel group 38 out of $48(\mathbf{7 9 . 2 \%})$ were considered as cured; and in the oxamniquine group 39 out of $46(84.8 \%)$. The difference was not statistically significant $(\mathrm{p}>0.1)$.

Rectal mucosa biopsies in 73 out of 77 patients with three negative stool examinations did not show viable eggs. 
SUVA, L. C. ds; ZEITUNE, J. M. R.; ROSA-EID, L. M. F.; LTMA, D. M. C.; ANTONELII, R. H.; CHRISTO, C. H.; SAJZ-ALQUEzar, A. \& CAFBONI, A. de C. - Treatment of patients with schistosomiasis: a double blind clinical trial comparing praziquantel with oxamniquine. Rev. Inst. Med, trop. São Paulo, 28:174-180, 1986.

T A B I E III

Biochemical data from schistosomotic patients before and after oxamniquine and praxiquantel

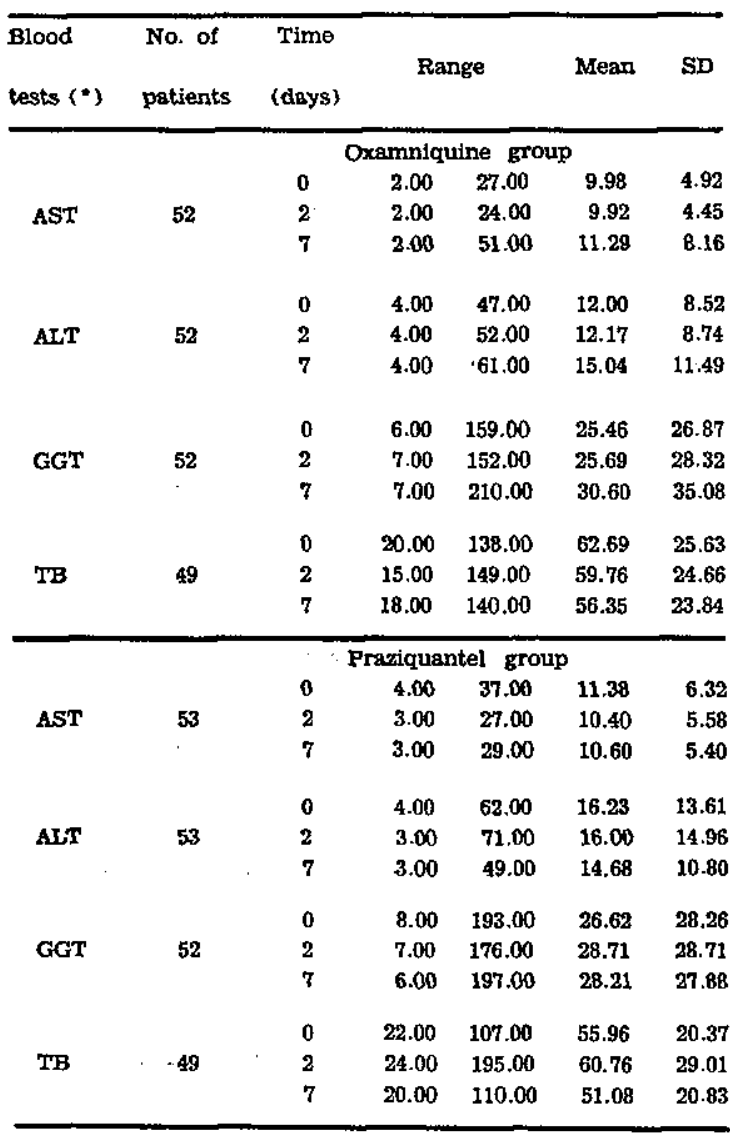

(*) AST, ALT, GGT, TB = aspartate and alanine amino. transferases, gammaglutamyl. transferase and total bilirubin

TA B L E IV

Results of statistical analysis comparing blood tests obtained before $\left(T_{0}\right)$ and two days $\left(T_{2}\right)$ and seven days $\left(T_{T}\right)$ after chemotherapy

\begin{tabular}{|c|c|c|c|c|}
\hline $\begin{array}{l}\text { Blood } \\
\text { tests }\end{array}$ & Hypothesis & $\mathbf{W}\left({ }^{*}\right)$ & $F(\star)$ & $\mathbf{p}$ \\
\hline \multirow{3}{*}{ ALT (**) } & $T_{0}=T_{2}$ & 0.9979 & 0.1058 & 0.7463 \\
\hline & $T_{a}=T_{\gamma}$ & 0.8741 & 7.3468 & 0.0091 \\
\hline & $\mathbf{T}_{\mathbf{z}}=\mathbf{T}_{\mathbf{T}}$ & 0.8003 & 5.6504 & 0.0212 \\
\hline \multirow{3}{*}{ GGT $(* *)$} & $\mathbf{T}_{0}=\mathbf{T}_{2}$ & 0.9979 & 0.1098 & 0.7417 \\
\hline & $\mathbf{T}_{0}=\mathbf{T}_{\mathbf{7}}$ & 0.8935 & 6.0785 & 0.0171 \\
\hline & $\mathbf{T}_{2}=\mathbf{T}_{1}$ & 0.8036 & 12.4659 & 0.0009 \\
\hline \multirow{3}{*}{ TB $(* *)$} & $\mathbf{T}_{0}=\mathbf{T}_{\mathbf{2}}$ & 0.9772 & 1.1189 & 0.2955 \\
\hline & $\mathbf{T}_{0}=\mathbf{T}_{\mathbf{z}}$ & 0.9633 & 1.8274 & 0.1828 \\
\hline & $T_{3}=T_{t}$ & 0.8715 & 7.0778 & 0.0106 \\
\hline
\end{tabular}

(*) Wilks and Fisher-Snedecor's statistics

(*) Alanine aminotransferase, gammaglutamyltransferase and total bilirubin
Considering the non-cured cases, except for one who received oxamniquine, all of them had a marked decrease in the mean number of eggs eliminated per gram of feces. The average reduction after praziquantel was $93.5 \%$ and after oxamniquine $84.1 \%$ (Table $\mathrm{V}$ ), a difference without statistical significance $(p>0.1)$.

Six out of the non-cured patients with praziquantel were treated again with the same drug. Five were followed up for six months and all were considered as cured.

Retreatment with oxamniquine was carried out in four out of seven non-cured patients. Three completed the follow-up and only one was cured. A non-cured case was retreated once more but with praziquantel achieving parasitological negativation.

\section{DISCUSSION}

These data show that praziquantel and oxamniquine produce similar side-effects, despite their different chemical structures and pharmacological properties. Only abdominal pain was more frequently observed with praziquantel. Most of the post-chemotherapy symptoms, although being frequent, were of slight or moderate intensity and did not require symptomatic medication.

The serum enzymatic changes observed after oxamniquine intake deserve some comments. It is a well-known fact that following chemotherapy there is a worm shift from the terminal mesenteric veins to the liver. Thus, the significant elevation of alanine-aminotransferase and of gammaglutamyltransferase found with oxamniquine might be due to worm embolization. As a matter of fact, an experimental study in infected and non-infected mice, undertaken in our laboratories has demonstrated that oxamniquine leads to worm embolization, focal hepatic necrosis and a significant increase in serum aminotransferase activity in the infected mice but no changes were seen in the control animals 27 . The absence of serum enzimatic alterations 7,30 and the elevation of serum total bilirubin after praziquantel -remain to be elucidated.

Parasitological nègativation occurred in $\mathbf{3 8}$ out of 48 patients $(79.2 \%)$ under praziquantel 
SILVA, L. C. da; ZEITUNE, J. M. R.; ROSA-EID, L. M. F.; LIMA, D. M. C.; ANTONELLI, R. H.; ChRYSTO, C. H.; SAEZ-ALOUEZAR, A. \& CARBONI, A. de C. - Treatment of patients with schistosomiasis: a double blind clinical trial comparing praxiquantel with oxamniquine. Fev. Inst. Med. trop. Săo Faulo, 28:174-180, 1986.

T A B L E V

Reduction of the number of $\mathbf{s}$. mansonl eggs per gram of feces after praziquantel and oxamniquine treatment in non-cured patients

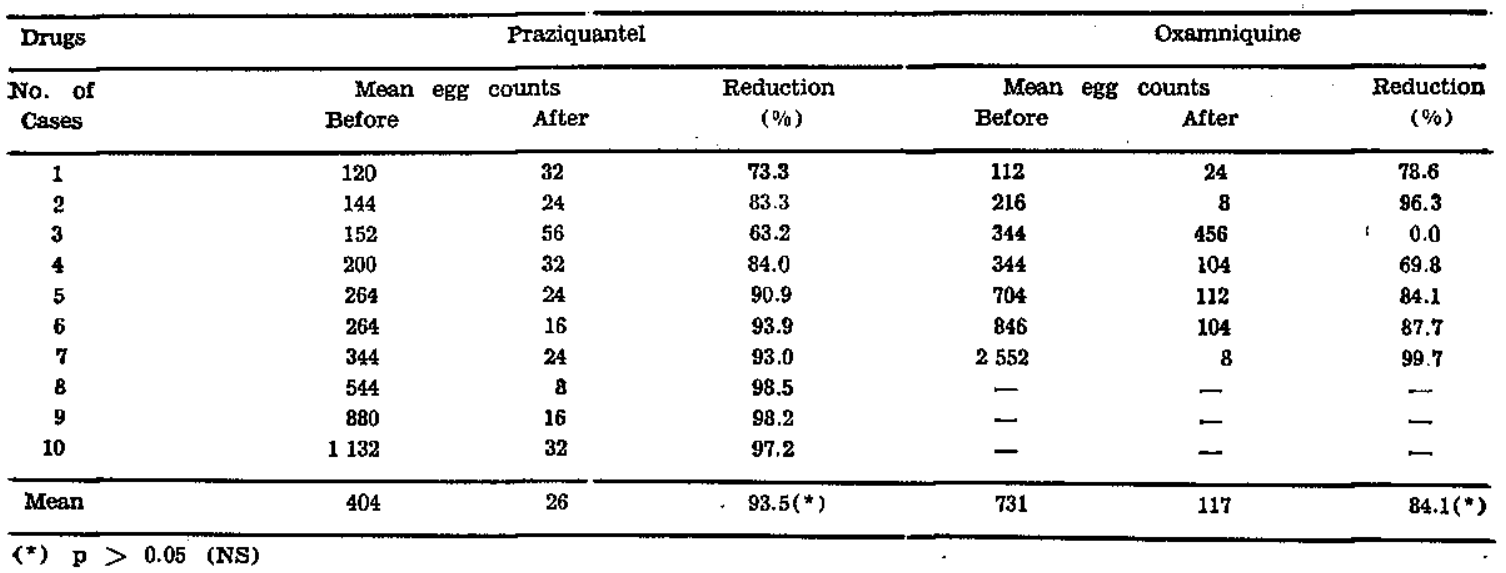

administration and in 39 out of $46(84.8 \%)$ under oxamniquine. Other investigators also have reported no significant difference between the efficacy of both drugs $3,13,20,21$, However, some of them referred a lower ${ }^{3}$ whereas others a higher ${ }^{13}$ cure-rate. For children, higher doses of praziquantel, $70 \mathrm{mg} / \mathrm{kg}$, as well as of oxamniquine, $20 \mathrm{mg} / \mathrm{kg}$, are necessary for achieving a cure-rate of about $70 \% \mathbf{1 2 , 2 3}$.

The results of retreatment are worth to be mentioned. Though the number of non-cured patients submitted twice to the same drug therapy is rather small, there was a tendency for the appearance of resistant cases to oxamniquine and apparently such occurrence does not influence the sensitivity of $\mathbf{S}$. mansoni to praziquantel ${ }^{11}$.

\section{RESUMO}

\section{Estudo clínico duplo cego comparando praxiquantel com oxamniquine}

Com objetivo de se compararem a tolerabilidade e eficácia do praziquantel e oxamniquine, procedeu-se a um estudo prospectivo duplocego envolvendo 120 pacientes com esquistossomose intestinal ou hepatintestinal.

Os pacientes foram randomizados em dois grupos. Um foi tratado com praziquantel, na dose de $55 \mathrm{mg} / \mathrm{kg}$ de peso, o outro com oxamniquine, $15 \mathrm{mg} / \mathrm{kg}$ de peso, sempre administra. dos em dose única por via oral. O diagnóstico e seguimento parasitológicos basearam.se no exame de fazes peìo método de Kato-Katz. Em 73 de 77 casos negativos após tratamento, executaram-se biopsias retais.

Efeitos colaterais, principalmente tontura. sonolência, dores abdominais, cefaléia, náuseas e diarréia foram observados em $87 \%$ dos casos. Sua incidēncia, intensidade e duração foram semelhantes em ambos os grupos, mas a dor abdominal foi significativamente mais frequiente após praziquantel, havendo maior tendência para tontura intensa após oxamniquine. Observou-se aumento significante de alamina-aminotransferase e gama-glutamiltransferase após oxamniquine e de bilirrubina total após praziquantel.

Um total de 48 pacientes tratados com praziquantel e $46 \mathrm{com}$ oxamniquine completaram os exames de controle até o sexto mês. As percentages de cura foram de $79,2 \%$ e de $84,8 \%$ respectivamente, diferença não significativa. Os pacientes não curados mostraram redução mé dia do número de ovos de $93,5 \%$ e de $84,1 \%$, diferença não significativa. Cinco pacientes retratados com praziquantel curaram-se, mas somente um de três retratados com oxamniquine.

Estes resultados mostram que ambas as drogas-apesar de diferentes propriedades farmacológicas - provocam reações colaterais semelhantes e apresentam eficácia terapêutica comparável. 
SILVA, L. C. da; ZEITUNE, J. M. R.; ROSA.EID, L. M. F.; LIMA, D. M. C.; ANTONELLI, R. H.; CHRISTO, C. H.; SAEZ-ALQUEZAR, A. \& CARBONI, A. de C. - Treatment of patients with schistosomiasis: a double blind clinical trlal comparing praziquantel with oxamniquine. Rev. Inst. Med. trop. Saso Maulo, 28:174.180, 1986.

\section{ACKNOWLEDGEMENTS}

To Dr. Getúlio L. de Rezende, Clinical Research Dpt. of Merck S. A. Ind. Quim., Rio de Janeiro, for his suggestions on the clinical trial protocol and for having provived the drugs.

\section{REFERENCES}

1. ARAƯJO, N.; RATZ, N.; DIAS, E. P. \& SOUZA, C. P. de - Susceptibility to chemoterapeutic agents of strains of Schistosoma mansonl isolated from treated and untreated patients. Amer. J. trop. Med. Hyg., 29: 890-894, 1980.

2. BiNA, 3. C. \& SPINOLA, A. - Convulsīo associada ao uso da oxaminiquine. Relato de um caso. Rev. Soc. bras. Med, trop., 10: 221-223, 1976.

3. BRANCHINI, M. L. M.; PEDRO, R. de J.; DIAS, L. C. de S. \& DEBERALDINI, E. R. - Double-blind clinical trial comparing praziquantel with oxamniquine in the treatment of patients with schistosomiasis man soni. Rev. Inst. Med. trop. S. Paulo, 24: 315-321, 1982.

4. BUAIS, V.; GONÇALVES, C. S.; ZANOTTI, W. M.; BONI, E. S. \& PEREIRA, F. E. I. - Experiéncia com hycanthone em 3.100 portadores de esquistossomose mansônica. Rev. Ass. méd. bras., 22: 171-174, 1976.

5. CAMPOS, R.; MOREIRA, A. A. B.; SETTE JR., H.; CHAMONE, D. A. F. \& SILVA, L. C. da - Hycanthone resistance in a human strain of Schistosoma mansoni. Trans. roy. Soc. trop. Med. Hyg., 70: 261-262, 1973.

6. COUTrNHo, A. - Tratamento da esquistossomose mansônica: aspectos atuais. Rev. Ass. méd. bras., 23: 27. 31, 1977.

7. COUTINHO, A. D.; DOMINGUES, A. L. C.; FLORENCrO, J. N. \& ALMEIDA, S. T. - Tratamento da esquistossomose mansónica hepatesplênica com praziquantel. Rev. Ynst. Med. trop. S. Paulo, 26: 38-50, 1984.

8. CUNHA, A. S. da - A avaliaçãa terapêutica da oxaminiquine na esquistossomose mansoni humana pelo método do oograma por biópsia da mucosa retal. Rev. Inst. Med. trop. S. Paulo, 24: 88.94, 1982.

9. DAVIS, A. - Management of the patient with schistosomiasis. In: JORDAN, P. \& WEBBE, G., ed. Schistosomiasis. Epidemiology, treatment and control. London, William Heinemann Medical Books, 1982. p. 184-226.

10. DIAS, L. C. de S.; PEDRO, R. J. RIGO, E.; GOTO, M. M. F. \& MAFRA, G. L. - Linhagem humana de schistosoma mansoni resistente a esquistossomicidas. Rev. Saúde públ., 12: 110, 1978.

11. DIAS, L. C. de S.; PEDRO, R. de J. \& DEBETAL DINI, E. R. - Use of praziquantel in patients with schistosomiasis mansont previously treated with oxamniquine and/or hycanthone: resistance of Schistosoms mansont to schistosomicidal agents. Trans. roy. Soc. trop. Med. Hyg., 76: 652-659, 1982.

12. EMANUEL, A. \& PRATA, A. - Praziquantel no tratamento da esquistossomose mansoni em crianças. Rev. Inst. Med. trop. S. Paulo, 25: 178-181, 1983.

13. EMANUEL, A. \& PRATA, A. - Comparação entre praziquantel e oxamniquine no tratamento da esquis. tossomose mansoni. Rev. Soc. bras. Med. trop., 16: $90-93,1983$

14. EVERITT, B. S. - The analysis of contingency tables. London, Chapman and Hall, 1977.

15. FROHBERG, H. \& SCHENCKING, M. S. - Toxicological profile of praziquantel, a new drug against cestode and schistosome infections, as compared to some other schistosomicides. Arzneim. Forsch./Drug Res., 31: 555-565, 1981.

16. GUTMARAES, R. X.; TChaKERTAN, A.; DIAS, L. C. da S.; ALMEIDA, F. M. R. de; VILELA, M. P; CA. BEÇA, M. \& TAKEDA, A. K. - Resistencia ao hy. canthone e oxamniquine em doentes com esquistossomo se forma clínica hepatintestinal. Rov. Ass. méd. bras. 25: $48-50,1979$

17. KATZ, N.; CHAVES, A. \& PELLEGRINO, J - A simple device for quantitative stool thick-smear technique in schistosomiasis mansoni. Rev. Inst. Med. trop. $S$. Paulo, 14: 397-400, 1972.

18. KATZ, N, - Experiências com quimioterapia em grande escala no controle da esquistossomose no Brasil. Rev. Inst. Med. trep. S. Paulo, 22: 40-51, 1980.

19. KATZ, N.; ROCHA, R. S. \& CHAVES, A. - Clinical trials with praziquantel in schistosomiasis mansoni. Rev. Inst. Med. trop. S. Paulo, 23: 72-78, 1981.

20. KATZ, N. \& ROCHA, R. S. - Double-blind clinical trial comparing praziquantel with oxamniquine in schistosomiasls mansoni. Rev. Inst. Med. trop. S. Paulo, 2A: 310-314, 1982.

21. KATZ, N.; ROCHA, R. S.; LAMEERTUCCY, J. R.: GRECO, D. B.; PEDROSO, E. R. P.; ROCHA, M. O. C. \& FLAN, S. - Clinical trial with oxamniquine and praziquantel in the acute and chronic phases of schis. tosomiasis mansoni. Rev. Inst. Med. trop. S. Paulo, 25: 173-177, 1983.

22. KILPATRICK, M. E.; FARID, Z.; BASSHY, S.; EL. MASRY, N. A.; TRABOLSI, B. \& WATTEN, R. H. Treatment of schistosomiasis mansoni with oxamniqui. ne - ftve years' experience. Amer. J. trop. Med. Hyg., 30: 1219-1222, 1981.

23. IAMRERTUCCI, J. R.; GRECO, D. B.; PFDROSO, E. R. P.; ROCHA, M. O. da C.; SALAZAR, H. M. \& LIMA, D. P. de - A double-blind trial with oxamaiquine in chronic schtstosomiasis mansoni. Trans. roy. Soc. trop. Med. Hyg., 76: 751-755, 1982. 
SEVA, L. C. da; ZEITUNE, J. M. R.; ROSA.EID, L. M. F.; LIMA, D. M. C.; ANTONELLI, R. H.; CHRISTO, C. H.; SAEZ-ALQUEZAR, A. \& CARBONI, A. de C. - Treatment of patients with schistosomiasis: a double blind clinical trial comparing praziquantel with oxamniquine. Rev. Inst. Med. trop. São Paulo, 28:174-180, 1986.

24. McMAhON, J. E. \& KOLTRUP, N. - Praziquantel: a new schistosomicide against Schistosome haematobium. Brit. Med. J., 2: 1396-1399, 1979.

25. NASH, T. E.; CHEEVER, A. W.; OTTESEN, E. A. \& COOK, J. A. - Schistosome infections in humans: perspectives and recent findings. Ann. intern. Med., 97: 740-754, 1982.

26. PRATA, A.; CaStro, C. N.; SILVA, A. E.; PAIVA, M.; MACEDO, V. \& JUNQUEIRA Jr., L. F. - Praziquantel no tratamento da esquistossomose mansoni. Rev. Inst. Med. trop. S. Paulo, 24: 95-103, 1982.

27. SAEZ-ALQUEZAR, A. - Niveis plasmáticos de atividade enximática da alanina aminotransferase, guanase e fosfatase alcalina em camundongos infestados por Schistosom mansoni e tratados com oxamniquina. Săo Paaulo, 1980. (Dissertação de mestrado - Faculdade de Ciências Farmacêuticas da Universidade de São Pauto).

28. SILVA, L. C. da; SETTE JR., H.; CHAMONE, D. A. F.; SAEZ-ALQUEZAR, A.; PUNSTAS, J. A. \& RAIA, S. - Further clinical trials with oxamniquine (UK
4271), a new anti-schistosomal agent. Rev. Inst. Med. trop. S. Paulo, 17: 307-311, 1975.

29. SILVA, L. C. da; SETTE JR., H.; CAMPOS, R.; MO REIRA, A. A. B. \& CHRISTO, C. H. - Resistance of Schistosoma mansoni to chemotherapy in human cases (abstract), Gastroenterology, 74: 1023, 1978

30. SILVA, L. C. da; SETTE JR., H.; CHRISTO, C. H.; SAEZ-ALQUEZAR, A.; CARNEIRO, C. R. W.; LACET, C. M.; OHTSUKI, N. \& RAIA, S. - Praziquantel in treatment of the hepatosplenic form of schistosomiasis mansoni. Arzneim. Forsch./Drug Res., 31: 601-603, 1981.

31. TIMM, N. H. - Multivariate analysis with applica. tions in education and psychology. Monterey, CA: Brooks/Cole, 1975.

32. ZHEJIANG CLINICAL COOPERATIVE RESEARCH GROUP FOR PRAZIQUANTEL - Clinicsi evaluation of praziquantel in treatment of schistosomiasts japonica. A repot of 181 cases. Chin. méd. J., 93: 375-384, 1980

Recebido para publicação em 29/8/1985. 